\title{
The Effectiveness of Health Education Using Leaflet and Video on Students' Knowledge About the Dangers of Smoking in Vocational High School 2 Purwokerto
}

\author{
1st Yessy Anggraeni \\ Undergraduate Science of Nursing \\ Student \\ Faculty Of Health Science \\ Harapan Bangsa University \\ Purwokerto, Indonesia \\ Yhesyangggraeni97@gmail.com \\ 4th lis Setiawan Mangkunegara \\ Nursing Lecturer \\ Faculty Of Health Science \\ Harapan Bangsa University \\ Purwokerto, Indonesia \\ iissmn@gmail.com
}

\author{
2nd Noor Rochmah Ida Ayu Tresno \\ Putri \\ Nursing Lecturer \\ Faculty Of Health Science \\ Harapan Bangsa University \\ Purwokerto, Indonesia \\ noorrochmah@uhb.ac.id
}

\author{
3rd Indri Heri Susanti \\ Nursing Lecturer \\ Faculty Of Health Science \\ Harapan Bangsa University \\ Purwokerto, Indonesia \\ indriherisusanti@uhb.ac.id
}

\begin{abstract}
Background: Health education is a planning effort for influencing, helping and giving protection so that the audience will be able to act based on expectation. The purpose of this study was to find out the the effectiveness of leaflet and video media in health education toward student knowledge about the danger of smoking at SMK Negeri 2 Purwokerto. The method of this study used pre experimental in one group with pre test post test design. The sampling technique was done with random sampling. The respondent in this study were 54 students of class $X$ then divided into two groups which contain of 27 students. The knowledge measurement of pre test and post test used questionnaire. The data analyzed using Wilcoxon and Man Whithney test. The result of this study show that dominated respondent is 16 years old male. Moreover, the knowledge before giving health education with leaflet media is in enough level as much $66,7 \%$ and the knowledge level is enough with video media as much $59,3 \%$. The knowledge level that dominated well after giving health education with leaflet media as much $\mathbf{7 7 , 8 \%}$ and video media as much $\mathbf{8 8 , 9 \%}$. Based on Wilcoxon test is obtained $p$ value $\leq \alpha(0,001 \leq 0,05)$ at leaflet media, $p$ value $\leq \alpha(0,000 \leq 0,05)$ at video media, therefore there is a different knowledge before and after giving heath education. Leaflet and video has the same effectiveness to increase student knowledge ( $p$-value $=\mathbf{0 , 2 7 8})$.
\end{abstract}

Keywords: health education, knowledge, leaflet, video

\section{INTRODUCTION}

Teens tend to have a great curiosity, because adolescence is a time where someone is still looking for its identity and labile mainly to environmental influences [1]. According to the Regulation of the Minister of Health (Minister) No. 25 of 2014, namely adolescent age range 1018 years of age [2]. Adolescence is a period where an individual experiencing a transition from one stage to the next as well as changes either interest, emotional, physical forms, patterns of behavior, and also experiencing various problems [3].

One risk issue that has a high prevalence in adolescence is smoking [4]. Smoking is one habit in the community committed by juveniles and adults. Teens school like SMU / SMK has been known to have a smoking habit [5].

Based on the survey results of the Global Adult Tobacco Survey (GATS), Indonesia is the country with the highest number of active smokers, ie $69.7 \%$ at age 15 and older [6]. National Health Survey (Sirkesnas) 2016 Basic Health Research (Riskesdas) in 2018 showed the increasing prevalence of tobacco consumption (hisapdan chewable) at the age of 15 years and above, namely from $32.8 \%$ to $33.8 \%$ [7]. The prevalence of smoking in Central Java province at the age of 15-19 years amounted to $48.5 \%$ [2]. Teens are already starting to smoke will have to continue smoking addiction, which resulted in disruption of health with a variety of chronic 
diseases. The increase in the prevalence of smoking among adolescents can lead to some impacts for individuals, the economy, and others.

Nine dangers of smoking for students that cause various diseases in the future, make the addiction, the beginning of drug abuse and drug, inhibits the achievement, especially in the field of sports, spending money pocket and trigger a crime, in violation of student discipline, bad breath that disrupt friendships and body become thin [8]. Kosen (2017) [9] asserted macro-economic losses due to cigarette consumption in Indonesia in 2015 reached almost Rp 600 billion or four times more than the number of cigarette tax in the same year ie almost Rp 140 trillion.

Green in Notoatmodjo (2011) [10] explains that there are several factors that influence a person's behavior, one of which is a predisposing factor which includes knowledge, attitudes, beliefs, beliefs, values, traditions, and so forth. The most dominant factor influencing smoking behavior in adolescents SMK is knowledge of adolescents about smoking [11]. Based on the results Rochayati (2015) [11] showed that most respondents are knowledgeable about as many as 274 people (78.96\%), and respondents who have a good knowledge of as many as 73 people $(25.36 \%)$.

Smoking behavior among adolescents is an activity that is "phenomenal", meaning that despite the known consequences of smoking but the number of teenagers who smoke is not decreasing but increasing. As a result, the problem of smoking behavior in adolescents in particular are very difficult to solve. Teenagers who smoke could threaten the future of the adolescent health and personality. Notoadmodjo (2007) in Andika (2016) [12] states that before a person adopts behaviors, he must first know what the meaning or benefit of such behavior towards themselves and their surroundings. Meanwhile, according Sholeh (2017) [8], the factors that cause young people smoking is smoking behavior of parents and the people around, the social environment such as peers, easy access to get cigarettes, and the deceitfulness of business conduct.

The government's efforts in reducing the number of smokers in Indonesia is listed in Government Regulation No. 109 of 2012 regarding the dangers of smoking message. This message must be listed on the packaging of cigarettes, with $40 \%$ of cigarette packaging penjabaraan list images from smoking and to be colored [13]. Aldani research results (2015) [14] states that the introduction of visual hazard warning on cigarette packs can reduce smoking behavior in adolescents. But according Salafudin in Afif (2015) [15] states that the ads on television and mass media, will affect teenagers to imitate and follow the behavior of the model in introducing the tobacco product.
Advertising in television and social media provides the image formed by the model in cigarette advertising so it looks as if people who smoke are successful, cool, mature and powerful can get through any obstacle. The number of ads in circulation today are always aims to create a good image for smokers in the cigarette when in fact there are chemicals that are harmful to health [15].

Another government effort contained in Law No.39 of 2009 on No Smoking Area (KTR) in public places. And Law No. 36 of 2009 on Health and PP 109 of 2012 on safeguarding danger containing addictive substances such as tobacco products to health also requires local governments set KTR through Regulation [8]. Until 2017 a total of 35 districts / cities in Central Java is already implementing KTR in 50\% of schools and $37.1 \%$ of districts / cities in Central Java have rules KTR in 2016 [16]. KTR implementation target not yet achieved in $50 \%$ of schools, it would require some effort at school one through the program is in place.

Efforts to prevent and control the habit of smoking among adolescents can be done in the order of schools through School Health Unit (UKS). UKS-achieving can be achieved with three main programs in coaching and development UKS, one of which is health education [17]. Nuradita research results (2013) [18], stating that there is influence of health education on knowledge about the dangers of smoking in adolescents in SMPN 3 Kendal. In addition the research results Ikhsan (2013) [19], concluded that health education about the dangers of smoking is proven to reduce tobacco consumption in adolescents. Some results of these studies showed that health education can increase knowledge and attitudes of adolescents, evidenced also by some other studies that assert various media as health education may affect adolescent knowledge.

Ambarwati research results (2014) [5], concluded that the use of leaflets media influence on students 'knowledge, whereas video media did not affect the students' knowledge. While Akmal (2015) [20] states that posters, leaflets and presentations are effective in improving the student's knowledge of the dangers of smoking. Rusmilawaty research results (2016) [21] concluded there's an influence of illumination with a lecture about the dangers of smoking on smokers active attitude. This can occur because the respondent and the different research sites.

According to a preliminary study conducted at SMK Negeri 2 Purwokerto by conducting interviews with 12 people teenager known five students have the smoking habit, 4 students have ever smoked, and three students had never smoked. Five students argue if smoke to relieve boredom, stress relief, entertainment, and soothe the mind. One of the students reasoned him smoke because there was as yet know the dangers of smoking. Schools have also implemented 
regulations smoking area and have not been carried out health education about the dangers of smoking before.

Based on the results of the mini-survey raises the interest the author to conduct research on "Effectiveness of Health Education Leaflets Media And Media Video tehadap Knowledge Students About Dangers of Smoking In SMK Negeri 2 Purwokerto".

\section{METHOD}

This study is a pre-experimental research with the study's design one group pretest posttest design. This research was conducted at SMK Negeri 2 Purwokerto on May 29, 2019. The study population was all students of class $\mathrm{X}$ in SMK Negeri 2 Purwokerto as many as 459 boys and 73 girls. The sampling technique uses the simple random sampling as many as 54 students were then divided into two groups so that each group consisted of 27 students who are willing to be respondents. The research instrument used was a questionnaire about the dangers of smoking were 24 multiple choice questions. Analysis of data using Wilcoxon test and Man Whitney test.

\section{RESULTS AND DISCUSSION}

Tabel 1 shows that the age of the respondents at SMK Negeri 2 Purwokerto largely dominated by the age of 16 years as many as 46 students ( $85.2 \%)$, while for sex as many as 47 students $(87.0 \%)$ male sex. Dominant male respondents due to the location of the study is one of the schools that interest boys that has a student population of men more than women.

TABLE 1. CHARACTERISTICS OF RESPONDENTS FREQUENCY DISTRIBUTION BY AGE AND GENDER

\begin{tabular}{|c|c|c|c|}
\hline \multicolumn{2}{|c|}{ Characteristics of Respondents } & Frequency & Percentage (\%) \\
\hline \multirow[t]{3}{*}{ Age } & 15 years old & 8 & 14,8 \\
\hline & 16 years old & 46 & 85,2 \\
\hline & Total & 54 & 100,0 \\
\hline \multirow[t]{3}{*}{ Gender } & Male & 47 & 87,0 \\
\hline & Female & 7 & 13,0 \\
\hline & Total & 54 & 100,0 \\
\hline
\end{tabular}

WHO in Lindawati (2012) [22] states that in making decisions that are at risk of men to behave more adventurous than women included in matters related to health such as alcohol consumption and smoking. According to the assumption of female researchers more easily receive information due to the habit of girls who are more diligent in seeking information than men and do not want too take risks, especially in terms of health.

Gunarsa in Putro (2017) [23] explains that in adolescence, middle (mid) are aged 15-17 years someone studying in high school / vocational school, This age have a greater desire to unknowns that would make teenagers seek out and this will affect comprehension as well as the mindset of someone [24]. Middle teens have some characteristics and there are different characteristics between men and women.

The survey results from WHO (2015) against high school students from 26 provinces in Indonesia showed that male students more likely to have risky behaviors related to smoking that is $22 \%$ in men and $1.6 \%$ for women.Based on the above explanation the researchers concluded that the respondents were in adolescents middle, where the age is a

period where a person has a great curiosity about something.

One of the risk behaviors in adolescents that smoking is mostly done by men than in women and increased from year to year. So teenagers need to be given health education about the dangers of smoking so that they can think about the dangers of smoking that can happen to themselves and others.

Based on Table 2 shows that out of 27 respondents who have enough knowledge level before being given health education using leaflets media as many as 18 students $(66.7 \%)$. In the video group, respondents who have enough knowledge level as many as 16 students $(59.3 \%)$.

TABLE 2. FREQUENCY DISTRIBUTION OF RESPONDENTS KNOWLEDGE BEFORE WERE GIVEN HEALTH EDUCATION IN SMK N 2 PURWOKERTO ( $=54)$

\begin{tabular}{|c|lc|c|c|c|}
\hline \multirow{2}{*}{ Level Knowledge } & \multicolumn{3}{c|}{ Leaflet Media } & \multicolumn{2}{c|}{ Video Media } \\
\cline { 2 - 7 } & \multicolumn{2}{|c|}{ f } & \% & f & $\%$ \\
\hline Well & 9 & 33.3 & 9 & 33,3 \\
\hline Enough & 18 & 66.7 & 16 & 59,3 \\
\hline Less & 0 & 0 & 2 & 7,4 \\
\hline
\end{tabular}

According to the researchers assuming sufficient level of knowledge that is because there are respondents who had received health education about the dangers of smoking before while still in junior high school (SMP), Besides already a lot of information about the dangers of smoking are easily obtained from advertising on television and in every pack of cigarettes, but the information submitted incomplete or not be covered even a teenager's attention. Some ads even show you if the cigarette is a sign of self-recognition, causing adolescent behavior often follows in the ad. There are several other factors that affect a person's knowledge.

Factors influencing knowledge, according Sukmadinata (2009) [24] is education, media / information, experience, environment and age. According to research Arif, et al (2015) [15] in the upgrading of knowledge can be done by providing health education or information from parents, teachers, the media, audio-visual and print. Some studies suggest that prior knowledge of health education by using media leaflets and video media is still in the poor category. 
Results of research conducted by Kasman, et al (2017) [25] showed 20 young people have less knowledge level as much as 13 teens $(65 \%)$ before being given a health education using the media leaflets about the dangers of smoking. Whereas before the media were given health education using video media mostly have sufficient knowledge of which 14 adolescents (70\%). This research was also supported by research Pertiwi (2018) which states thatrespondents have less knowledge well before the intervention of the dangers of smoking by 97 (72.4\%).

Based on the above researchers assume that the required health education using other media such as leaflets which involves the senses of vision and video that involves the senses of vision at the same hearing that teenagers can better understand the dangers of smoking so that the level of knowledge of adolescents become better which can reduce risky behaviors in adolescents that smoking.

TABLE 3. FREQUENCY DISTRIBUTION OF RESPONDENTS KNOWLEDGE AFTER WERE GIVEN HEALTH EDUCATION IN SMK N 2 PURWOKERTO $(\mathrm{N}=54)$

\begin{tabular}{|c|cc|cc|}
\hline \multirow{2}{*}{$\begin{array}{c}\text { Level } \\
\text { Knowledge }\end{array}$} & \multicolumn{2}{|c|}{ Leaflet Media } & \multicolumn{2}{|c|}{ Video Media } \\
\cline { 2 - 5 } & $\mathbf{f}$ & $\boldsymbol{\%}$ & f & $\%$ \\
\hline Well & 21 & 77.8 & 24 & 88.9 \\
\hline Enough & 6 & 22.2 & 3 & 11.1 \\
\hline Less & 0 & 0 & 0 & 0 \\
\hline
\end{tabular}

The results showed that the respondents' knowledge at SMK Negeri 2 Purwokerto after given health education about the dangers of tobacco use leaflet media and video media alike predominantly have good knowledge that a number of 21 students $(77.8 \%)$ and 24 students $(88.9 \%)$.

Researchers in health education using leaflets media and video media about the dangers of smoking. According Ambarwati et al (2014) [5] in his study claimed that the leaflet media can convey a message explicitly clear, and can be read repeatedly by students. While media images and audio video displays utilizing two senses are vision and hearing. Both media have advantages respectively.

Leaflet one of the property that are prepared based on the principle that human knowledge is received or captured through the five senses. Leaflets good is to use simple language, easily understood by readers, the title used interesting to read and combined between text and images, as well as the material in accordance with the intended target. Besides video media is media types in addition to containing elements of the voice also contains elements of the image that can be seen so that better and more interesting, because it contains two elements, that is heard and seen [10]. Through the medium of video is expected to be more effective health education to increase knowledge about the dangers of smoking.
The results are consistent with research Kasman (2017) [25] which prove that health education using leaflets media and video media can improve students' knowledge about the dangers of smoking. Based on these results, researchers assume that the selection of appropriate health education media in the delivery of health education can affect a person's knowledge for the better. Health education leaflets media and video media to increase knowledge for utilizing the senses of vision and sense of hearing.

TABLE 4. DIFFERENCES KNOWLEDGE LEAFLET GROUP WERE GIVEN BEFORE AND AFTER HEALTH EDUCATION ( $=27)$

\begin{tabular}{|c|c|c|c|c|}
\hline & & Mean & Difference & P value \\
\hline \multirow{2}{*}{$\begin{array}{c}\text { Leaflet } \\
\text { Media }\end{array}$} & Pre-test & 2,33 & \multirow{2}{*}{0,45} & 0,001 \\
\cline { 2 - 3 } & Post-test & 2,78 & & \\
\hline
\end{tabular}

The results showed difference level of knowledge before and after the media were given health education leaflets about the dangers of smoking with a difference an increase of 0,45 , and the significance value of 0,001 ( $p$ value $<0,05$ ). The results are consistent with Kasman (2017) which prove that there are differences in the level of knowledge before and after in the given health education using leaflets media on teenagers about the dangers of smoking.

In this study, researchers provide health education about the dangers of tobacco use leaflet media are packed in colorful pictures and writings contain about ingredients contained in cigarettes, the dangers of smoking, as well as the hazard of smoking for students who are awarded for 15 minutes.

Based on the results, the results are a lot of unknown knowledge the student before the media were given health education leaflet is about the effects of substances contained in cigarettes such as tar $(85.1 \%)$, oxidant gas $(77.7 \%)$, nicotine $(29.6 \%)$, benzene $(40.7 \%)$, and three kinds of substances in cigarettes (96.2\%). According to the assumptions of researchers, lack of knowledge of students regarding this case because at the vocational school no health education about the dangers of smoking, but there are some students who have received earlier so that students have not been in knowledge of chemical substances contained drawing this non or less attention to even forget about substances contained in cigarettes when getting the knowledge beforehand.

Besides the above there are still many students who do not know from cigarettes to organs such as the oral cavity $(70.3 \%)$ and for bone (48.1\%). Overall the students already have a good knowledge about the dangers of smoking to the body organs such as the heart, lungs, skin, reproductive and brain as well as the dangers of smoking for students. According to the researchers, this assumption can occur because students are used to seeing cigarette ads that contain about the dangers of smoking on television, print media, as well as cigarette packs. 
After being given health education using leaflets about the dangers of smoking media containing colorful pictures and writings of students' knowledge obtained predominantly have good knowledge about the effects of substances contained in cigarette smoke mapun danger to the health of organs. It can happen because the students gain new knowledge about substances contained in cigarettes and the dangers of smoking from the leaflet that has been given by the researchers.

Media leaflets are used as a medium for health education because in this media target can adjust and learn independently, users can view the contents while relaxing, information can be shared with family and friends, can provide more details about the information that can not be administered orally and reduce the need for record [11] .

The above statement is not in accordance with the opinion of Alini (2018) [26] which states that the media leaflet has the disadvantage that only contains images and text alone so only use one senses that vision. Although media leaflet has shortcomings, but the information provided can be conveyed properly to the respondents, resulting in increased value and average knowledge of the respondents in the posttest.

Ambarwati (2014) [5] concluded that health education leaflets media more effectively to improve the knowledge of elementary school students about the dangers of smoking. Based on the description above, researchers assume that the media is able to increase knowledge of adolescents leaflets about the dangers of smoking although it has shortcomings. So it can be used as one of the medium used to deliver health education on the dangers of smoking.

TABEL 5. DIFFERENCES KNOWLEDGE VIDEO GROUP WERE GIVEN BEFORE AND AFTER HEALTH EDUCATION ( $\mathrm{N}=27)$

\begin{tabular}{|l|c|c|c|c|}
\hline \multicolumn{2}{|c|}{} & Mean & Difference & P value \\
\hline $\begin{array}{l}\text { Video } \\
\text { Media }\end{array}$ & Pre-test & 2,26 & \multirow{2}{*}{0,63} & 0,000 \\
\cline { 2 - 3 } & Post-test & 2,89 & & \\
\hline
\end{tabular}

Based on the results of the bivariate test using Wilcoxon test gained an average pre-test 2,26 and post-test 2,89 knowledge knowledge which means there is an increase of 0.63 , and the $\mathrm{p}$ value of 0.000 ( $\mathrm{p}$ value $<0.05$ ). These results address that there is the effect of health education using video media to increase knowledge about the dangers of smoking.

Based on the results, the results are a lot of unknown knowledge of students before being given a health education video media is about the effects of substances contained in cigarettes such as tar $(70.3 \%)$, oxidant gas $(92.5 \%)$, nicotine $(29.6 \%)$, benzene $(33.3 \%)$, and three kinds of substances in cigarettes $(100 \%)$. According to the assumptions of researchers, students' lack of knowledge about this case because the student is not in knowledge of chemical substances contained cigarettes or drawing this lack of attention to even forget about the substances contained in cigarettes when getting the knowledge beforehand.

Besides the above there are still many students who do not know from cigarettes to organs such as the oral cavity $(59.2 \%)$ and for bone (59.2\%). Overall the students already have a good knowledge about the dangers of smoking to the body organs such as the heart, lungs, skin, reproductive and brain as well as the dangers of smoking for students. According to the researchers, this assumption can occur because students are used to seeing cigarette ads that contain about the dangers of smoking on television, print media, as well as cigarette packs.

The results of the study together with the media leaflets that after being given health education using videos about the dangers of smoking that contains images as well as moving the color, text, and voice obtained knowledge students alike predominantly have good knowledge about the effects of substances contained in cigarettes and the dangers of smoking for the health of the organs. It can happen because the students gain new knowledge about substances contained in cigarettes and the dangers of smoking from the video that has been provided by the researchers.

According to Saban (2017) [27] videoan intermediary media which matter and absorption through sight and hearing to establish the conditions to enable the pupils to acquire knowledge and skills. The material in the form of packaged video image effects that move with an interesting storyline and voice so as to provide a more concrete picture.

The results are consistent with research Kasman (2017) [25] that the video media influence on adolescent knowledge about the dangers of smoking and Saban (2017) [27] that the video media berpengarguh to the knowledge of anemia in SMAN 2 choosed, Sleman. However, this result is not consistent with research Ambarwati (2014) [5] which states that health education video media dnegan no effect on students' knowledge SDN 68 Sabrang Lor about the dangers of smoking. This can occur because of differences in the respondents, the research Saban (2017) [27] respondents were high school students and on Ambarwati (2014) [5] respondents are elementary school students. High school students and elementary school students have different abilities in receiving information.

Based on the above statement shows the differences in the results of several researchers. According to the assumptions of researchers for this difference is because the research Ambarwati (2014) [5] respondents are children (elementary students) while on study Kasman (2017) [25] and Saban (2017) [27] respondents are teenagers. Children and adolescents age difference will affect the mindset and acceptance of the message, because adolescents are more 
easily absorb the message in the video of the children (elementary students).

Researchers also assume that knowledge changes can occur due to adolescent health education about the dangers of tobacco use video media that is packaged in a colorful and moving images, sound, and little has been written so that teens are interested to observe the course of the video as well as to understand the content of the displayed video.

TABEL 6. ANALYSIS KNOWLEDGE AFTER WERE GIVEN HEALTH EDUCATION

\begin{tabular}{|c|c|c|c|}
\hline $\begin{array}{c}\text { Media Health } \\
\text { Education }\end{array}$ & N & Mean & P-value \\
\hline Leaflet Media & 27 & 26,00 & \multirow{2}{*}{0,278} \\
\hline Video Media & 27 & 29,00 & \\
\hline
\end{tabular}

The results of different tests using Man Whitney test was obtained p value 0.278 , greater than 0.05 so $\mathrm{H} 0$ is accepted and Ha rejected. This means showed no significant difference betweenrespondents' knowledge after health education by using media leaflets and video media about the dangers of smoking at SMK Negeri 2 Purwokerto.

From the results, the average value of media use leaflets and video media is almost the same, namely the difference 3, where the average post test group leaflets and post test 26.00 29.00 video group. It can be concluded that health education using leaflets media and video media are equally effective to increase students' knowledge about the dangers of smoking at SMK Negeri 2 Purwokerto.

According to the researchers hypothesized that the expected did not show up because at the time of sampling the researchers did not conduct screening in advance of respondents regarding've ever or never received health education about the dangers of smoking. Thereby allowing the majority of respondents already mengetahuai partially or completely about the dangers of smoking. Supposedly investigators conducted the initial screening beforehand, in the hope of hypotheses that are expected to arise.

Knowledge can be interpreted as an impression in the minds of men as a result of the use of his senses [28]. Knowledge is one that has great influence in the formation of behavior that is realized by the knowledge that is lasting [10]. One of the things that can be done to improve one's health knowledge, namely the need for health education was given.

Health education is any deliberate attempts to influence, provide protection and assistance so that participants have the ability to behave as expected [29]. In this research, health education media used are media leaflets and video media.

Media leaflet contains information about the dangers of smoking in the form of text, images, and colors that appeal. Leaflets have the advantage of being able to customize a teenager in view information about the dangers of smoking.
Based on the survey results revealed that there is a change in the average value of knowledge before and after using the health pendindidikan given leaflets media ie from 2.33 to 2.78 .

Media video in this study contains about the dangers of smoking in the form of voice, text, and color motion pictures interesting. Media video has advantages in addition to containing elements of the voice also contains elements of the image that can be seen so that better and more interesting, because it contains two elements, that is heard and seen [10]. Based on the survey results revealed that there is a change in the average value given the knowledge before and after health pendindidikan using video media, namely from 2.26 to 2.89 .

Based on the description above, researchers assume that despite health education using leaflets media and video media are equally influential on students' knowledge about the dangers of smoking, but the video media is more effective than leaflets media. Because through video media information submitted will be more clearly and take advantage of the two senses at once, namely vision and hearing. Besides video media are more flexible in giving an explanation of the concept of matter and details of certain skills because video usually directly describe the information by way of illustration.

In addition to the above reasons, the researchers also found that explanation is presented in a video more unbiased and complete than in a leaflet given on the leaflet there is limited scope. Overall video media can provide a better learning experience than on media leaflet. But that does not mean the media leaflet can not give effect to the knowledge of the dangers of smoking. Various media has its advantages, so good for use during in accordance with conditions on the ground.

The highest effectiveness in a health education requires or involves multiple senses at once. De Porter in Dewina (2015) states that humans can absorb the material as much as $70 \%$ of what is done, $50 \%$ of what is heard and seen (audiovisual), while it sees only $30 \%$, of which he heard only $20 \%$, and from being read only $10 \%$. From the results of these studies, the percentage obtained from hearing just only $20 \%$, while the percentage of viewing and listening (audio visual) is much larger, namely $50 \%$.

\section{CONCLUSIONS}

The results showed that respondents were predominantly aged 16 years and male gender and health education using leaflets media and video media are equally effective to increase students' knowledge about the dangers of smoking. Researcher assume that the video media is more effective than leaflets media. Because through video media information submitted will be more clearly and take advantage of the two senses at once, namely vision and hearing. 
Pada Bungkus Rokok Terhadap Perilaku Merokok Pada Siswa SMA," J. Ilmu keperawatan, vol. 3, no.

\section{SUGGESTION}

This study can serve as a source of information and applied in the selection of methods and media are effective in the delivery of health education about the dangers of smoking, especially to adolescents.

Educational institutions can make this as an input on the importance of health education on the dangers of smoking to improve the information and implement the smoking ban, as well as working with parents through meetings every semester between parents with homeroom teacher or the school to discuss the academic progress of students and student behavior in schools to prevent juvenile delinquency.

\section{REFERENCES}

[1] M. Ali and M. Asrori, Psikologi Remaja: Perkembangan Peserta Didik. Jakarta: PT. Bumi Aksara, 2011.

[2] M. RI, "Peraturan Menteri Kesehatan Republik Indonesia Nomor 25 Tahun 2014 Tentang Upaya Kesehatan Anak.," 2014.

[3] et al Nurmiyanto, "Sosialisasi Bahaya Rokok Guna Meningkatkan Kesadaran Masyrarakat Akan Besarnya Dampak Buruk Rokok Bagi Kesehatan," J. Inov. dan Kewirausahaan, vol. 2, p. 225, 2013.

[4] E. et al Wijayanti, "Faktor-faktor yang Berhubungan dengan Perilaku Merokok pada Remaja Kampung Bojong Rawalele, Jatimakmur, Bekasi," Glob. Med. Heal. Commun., vol. 5, no. 3, p. 194, 2018.

[5] Ambarwati, "Media Leaflet, Video Dan Pengetahuan Siswa SD Tentang Bahaya Merokok (Studi Pada Siswa SDN 78 Sabrang Lor Mojosongo Surakarta," J. Masy. Kesehat., vol. 10, no. 8, 2014.

[6] GATS, "Global Adult Tobacco Survey (GATS),Indonesia Report.” 2011.

[7] B. K. RI, RISKSDAS 2018: Hasil Utama RISKESDAS 2018. Jakarta: Balitbang Kemenkes RI.

[8] S. AN, Panduan Anti Merokok Untuk Pelajar, Guru, Dan Orang Tua. Jakarta: Erlangga, 2017.

[9] S. Kosen, "Health and Economic Cost of Tobacco in Indonesia: Review of Evidence Series." Lembaga Penerbit Badan Penelitian dan Pengembangan Kesehatan (LPB)., 2017.

[10] Notoatmodjo, Promosi Kesehatan dan Perilaku Kesehatan. Jakarta: Rineka Cipta, 2012.

[11] Rochayati, A. Siti, and E. Hidayat, "Faktor-Faktor Yang Mempengaruhi Perilaku Merokok Remaja Di Sekolah Menengah Kejuruan Kabupaten Kuningan," J. Keperawatan Soedirman (The Soedirman J. Nurs., vol. 10, no. 1, 2015.

[12] et al Andika, "Hubungan Pengetahuan Dengan Kejadian Merokok Pada Pelajar SMPN 1 Pariaman," J. Kesehat. Andalas, vol. 5, no. 2, 2016.

[13] Puput, "Jumlah Perokok Terus Meningkat, Indonesia Tertinggi Kedua Di Dunia.” 2014.

[14] N. A. et al Aldani, "Pengaruh Peringatan Visual
[15] A. N. Afif and K. Astuti, "Hubungan Antara Persepsi Terhadap Iklan Rokok Dengan Perilaku Merokok Pada Remaja," InSight, vol. 17, no. 1, 2017.

[16] K. RI, Profil Kesehatan Indonesia 2016. Jakarta: Kemenkes RI 2017, 2017.

[17] L. Wahyuni, "Efektifitas Health Education (HE) Media Booklet Tentang Bahaya Merokok Terhadap Tingkat Pengetahuan Remaja Di SMPN 1

Mojoanyar," vol. 13, no. 1.

[18] Nuradita and Mariyam, "Pengaruh Pendidikan Kesehatan terhadap Pengetahuan tentang Bahaya Rokok pada Remaja di SMP Negeri 3 Kendal," $J$. Keperawatan Anak, vol. 1, no. 1, 2013.

[19] H. Ikhsan, "Pengaruh Pendidikan Kesehatan Bahaya Merokok terhadap Perilaku Men $\neg$ gurangi Konsumsi Rokok pada Remaja (Studi Kasus di Dukuh Kluweng Desa Ke $\neg$ jambon Kecamatan Taman kabupaten Pe $\neg$ malang," J. Ilmu Keperawatan dan Kebidanan, vol. 2, no. 1, 2013.

[20] S. Z. et al Akmal, "Program Pemberian Informasi Bahaya Merokok Melalui Leaflet, Presentasi Dan Poster," Pros. SNaPP 2015 Kesehat., vol. 1, no. 24, 2015.

[21] Rusmilawaty, "Rusmilawaty. 2016. Pengaruh Penyuluhan Metode Ceramah Tentang Bahaya Merokok Terhadap Perubahan Sikap Perokok Aktif," J. Vokasi Kesehat., vol. 2, no. 2, 2016.

[22] Lindawati, Miradwiyana, Bara, and Sumiati,

"Faktor-Faktor Yang Mempengaruhi Perilaku

Merokok Siswa-Siswi SMP Di Daerah Jakarta Selatan Tahun 2011," J. Heal. Qual., vol. 2, no. 4, 2012.

[23] K. Z. Putro, "Memahami Ciri dan Tugas Perkembangan Masa Remaja," J. Apl. Ilmu-ilmu Agama, vol. 17, no. 1, 2017.

[24] N. . Sukmadinata, Landasan Psikologi Proses Pendidikan. Bandunng: PT. Remaja Rosdakarya, 2009.

[25] et al Kasman, "Studi Eksperimen Penggunaan Media Leaflet Dan Video Bahaya Merokok Pada

Remaja," J. Publ. Kesehat. Masy. Indones., vol. 4, no. 2,2017

[26] Alini, "Efektifitas Promosi Kesehatan Melalui Audio Visual Dan Leaflet Tentang Sadari (Pemeriksaan Payudara Sendiri) Terhadap Peningkatan Pengetahuan Remaja Putri Tentang Sadari Di SMAN 1 Kampar Tahun 2018," J. Ners, vol. 2, no. 2, 2018.

[27] S. Saban, "Efektifitas Media Videodan Leaflet Terhadap Pengetahuan Tentang Anemia Siswi Sman 2 Ngaglik SlemanNo Title," Naskah Publ., 2017.

[28] W. . Mubarak, Promosi Kesehatan Sebuah Pengantar Proses Belajar Mengajar Dalam Pendidikan. Jakarta: Graha Ilmu, 2011.

[29] W. R. Induniasih, Promosi Kesehatan : Pendidikan Kesehatan Dalam Keperawatan. Yogyakarta: Pustaka Baru Press, 2017. 